\title{
Seven Pack
}

National Cancer Institute

\section{Source}

National Cancer Institute. Seven Pack. NCI Thesaurus. Code C78779.

A product containing seven individual units. 